\title{
Anxiety Disorder Associated with the COVID-19 Pandemic Causes Deterioration of Blood Pressure Control in Primary Hypertensive Patients
}

\section{COVID-19 Pandemisi Kaynaklı Anksiyete Bozukluğu Primer Hipertansif Hastalarda Kan Basıncı Kontrolünün Bozulmasına Sebep Olmaktadır}

\author{
Mehmet CELIK $\odot$, Yusuf YILMAZ $\odot$, Ali KARAGOZ $\odot$, Muzaffer KAHYAOGLU $\odot$, Ender Ozgun CAKMAK $\odot$ \\ Ayhan KUP $\odot$, Fatma Betül CELIK $\odot$, Ahmet KARADUMAN $\odot$, Seyhmus KULAHCIOGLU $\odot$, Servet IZCI $\odot$ \\ Cetin GECMEN $\odot$, Mustafa CALISKAN $\odot$
}

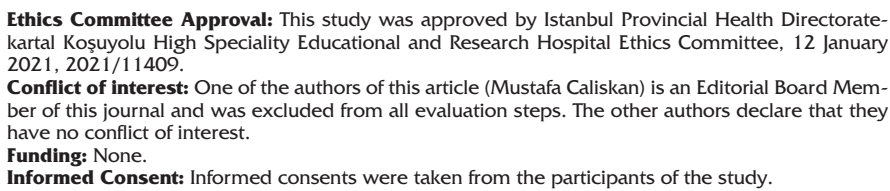

Ethics Committee Approval: This study was approved by Istanbul Provincial Health Directoratekartal Koşuyolu High Speciality Educational and Research Hospital Ethics Committee, 12 January 2021, 2021/11409.

Conflict of interest: One of the authors of this article (Mustafa Caliskan) is an Editorial Board Member of this journal and was excluded from all evaluation steps. The other authors declare that they have no conflict of interest.

Funding: None.

Informed Consent: Informed consents were taken from the participants of the study.

Cite as: Celik M, Yilmaz Y, Karagoz A, et al. Anxiety disorder associated with the COVID19 pandemic causes deterioration of blood pressure control in primary hypertensive patients. Medeni Med J. 2021;36:83-90.

\begin{abstract}
Objective: The new coronavirus disease (COVID-19) has spread rapidly all over the world and caused anxiety disorders. Recent studies have also shown that the prevalence of depression and anxiety increased during the COVID-19 outbreak. We aimed to evaluate the anxiety and depression levels during the pandemic and identify the effect of pandemic-related stress on blood pressure (BP) control in primary hypertensive patients.

Method: A total of 142 patients with primary hypertension (HT) who continued to use the same antihypertensive drugs before and during the pandemic were included in the study. Twenty-four -hour Ambulatory Blood Pressure Monitoring (ABPM) and the Hospital Anxiety and Depression Scale (HADS) questionnaire were applied to patients. We retrospectively reviewed 24-h ABPM records of the same patients for the year before the pandemic.

Results: Daytime, nighttime and 24 -hour-systolic blood pressure (SBP) levels as well as daytime, nighttime, and 24- hour-diastolic blood pressure (DBP) levels, were significantly elevated during the COVID-19 outbreak compared to the pre-pandemic period $(p<0.001)$. Higher HADS-A scores (HADS-A $\geq 7)$ were significantly associated with much greater increase in $B P$ compared to the patients with lower HADS-A scores.

Conclusion: Psychological stress due to the COVID-19 outbreak led to worsening of the regulation of $B P$ in controlled hypertensive patients whose antihypertensive treatments did not change.
\end{abstract}

Keywords: COVID-19; pandemic; hypertension; anxiety

Öz

Amaç: Yeni koronavirüs hastalığı (COVID-19) tüm dünyada hızlı bir şekilde yayılarak anksiyete bozukluğuna sebep olmuştur. Yakın zamanlı çalışmalar, COVID-19 salgıııı sırasında depresyon ve anksiyete prevalansında artıs olduğunu göstermiștir. Biz bu çalıșmamızda primer hipertansif hastalarda, pandemi sırasında anksiyete ve depresyon düzeylerini değerlendirmeyi ve pandemiye bağlı stresin kan basıncı kontrolü üzerindeki etkisini belirlemeyi amaçladık.

Yöntem: Pandemi öncesinde ve sırasında aynı antihipertansif ilaçları kullanmaya devam eden toplam 142 primer hipertansiyon hastası çalışmaya dahil edildi. Bu hastalara 24 saatlik Ambulatuar Kan Basıncı Monitorizasyonu (AKBM) yapıldı ve Hastane Anksiyete ve Depresyon Ölçeği (HADS) anketi uygulandı. Pandemiden önceki son 1 yıl için aynı hastaların 24 saatlik AKBM kayıtlarını geriye dönük olarak incelendi.

Bulgular: Gündüz, gece ve 24 saat sistolik kan basıncı ile gündüz, gece ve 24 saat diyastolik kan basıncı, COVID-19 salgını sırasında pandemi öncesi döneme kıyasla önemli ölçüde yükseldi ( $p<0.001)$. Daha yüksek HADS-A skorları (HADS-A 7), daha düşük HADS-A skoruna sahip hastalara kıyasla kan basıncında çok daha fazla artışla anlamlı şekilde iliş̧kilendirildi.

Sonuç: COVID-19 salgınına bağlı psikolojik stres, antihipertansif tedavileri değişmeyen kontrollü hipertansif hastalarda kan basıncı regülasyonun bozulmasına sebep olmuştur.

Anahtar kelimeler: COVID-19; pandemi; hipertansiyon; anksiyete
Received: 8 March 2021

Accepted: 8 May 2021

Online First: 18 June 2021

Corresponding Author: M. Celik

ORCID: 0000-0003-0364-2239

Kartal Kosuyolu Education and Research Hospital,

Department of Cardiology, Istanbul, Turkey

memo.373234@gmail.com -0438-2021 ORCID: 0000-0002-8572-1725

E.O. Cakmak ORCID: 0000-0001-6767-6935 A. Kup

ORCID: 0000-0003-1977-069X ORCID: 0000-0002-4039-1259 S. Kulahcioglu ORCID: 0000-0002-6435-7821 S. Izci ORCID: 0000-0002-4021-3444 C. Gecmen ORCID: 0000-0001-8542-036X Kartal Kosuyolu Education and Research Hospital,

Department of Cardiology, Istanbul, Turkey

Y. Yilmaz ORCID: 0000-0002-6676-2740 F.B. Celik ORCID: 0000-0003-4472-4847 M. Caliskan ORCID: 0000-0001-7417-4001 Istanbul Medeniyet University, Department of Cardiology, Istanbul, Turkey 


\section{INTRODUCTION}

The novel coronavirus disease (COVID-19) broke out in China in December 2019 and subsequently spread rapidly all over the world. The first case was reported on March 11, 2020 in Turkey and then the number of cases have increased rapidly. Various precautions were adopted to prevent spread of the virus including reducing social contact, interruption of education, postponement of elective surgeries, and restriction of hospital admissions except for emergencies. Beyond the medical risk, social isolation is a well-known risk factor causing psychological and psychiatric disorders in the general population ${ }^{1}$. Moreover, the rapid spread and deaths due to COVID19 disease have negatively affected people's physical and mental health, caused depression and anxiety ${ }^{2}$. Recent studies have also shown that the prevalence of depression and anxiety has increased during the COVID-19 outbreak $^{3}$. Psychological stress has a significant impact on the cardiovascular system, and changes in emotional state can cause fluctuations in $\mathrm{BP}$ control $^{4}$. Previous studies have also shown that anxiety disorders and depression are correlated with BP variability ${ }^{5,6}$ Seeing that increased psychological stress is strongly associated with impaired BP control, we hypothesized the pandemic as a possible cause of psychological stress, may be associated with impaired BP control in patients with primary HT. The aim of this study was to evaluate the anxiety and depression levels during the pandemic, and identify the effect of pandemic-related stress on BP control in primary hypertensive patients.

\section{MATERIAL and METHOD}

\section{Study Population}

This cross-sectional study included primary hypertensive outpatients who had been treated in a tertiary heart center for the last three years. The 24-h ABPM, and the HADS questionnaires were applied to the patients who presented to the outpatient clinic during the pandemic. We also retrospectively reviewed the 24-h ABPM records of these patients for the the year before the pandemic. A total of 142 patients with primary HT who used the same antihypertensive drugs before and during the pandemic were included in the study.

Patients included in the study had no history of COVID-19 infection or vaccine. All patients were asked if there was any psychological stress source that would cause a change in their psychosocial status other than COVID-19 in the previous year, and whether there was a history of referral to a psychiatrist or using psychiatric medication. Patients with any of these conditions were excluded from the study. Patients with a history of serious physical stress such as trauma, injury, infection, or surgery within the previous year were also excluded from the study. Thus, the Covid-19 pandemic was the main psychosocial stress factor for the study patients. In addition, patients with secondary or uncontrolled HT, chronic renal failure (glomerular filtration rate $<60 \mathrm{~mL} / \mathrm{min}$ ), diabetes mellitus, heart failure (ejection fraction $<40 \%$ ), malignancy, excessive alcohol intake, any known psychiatric disorders or psychiatric drug use were excluded from the study. We also excluded patients who did not use antihypertensive drugs regularly, or during the pandemic or could not access medication due to the pandemic conditions.

Height, weight, and waist circumference of all patients were measured during outpatient clinic visits. The body mass index (BMI) was calculated as weight $(\mathrm{kg}) /$ height $^{2}(\mathrm{~m})^{2}$.

Patients' clinical and demographic characteristics, drugs used before and during the pandemic were obtained from medical records and from follow-up data collected during outpatient clinic visits. The study was approved by the local ethics committee and conducted in accordance with the ethical principles of the Declaration of Helsinki. 


\section{Ambulatory blood pressure monitoring}

Noninvasive ambulatory BP and heart rate measurements were carried out using the ambulatory Custo screen 300 (Custo medical Gmbh products, Germany) scheduled for every 15 minutes between 07:00 and 22:00, and every 30 minutes between 22:00 and 07:00. The cuff of the manometer was placed on the patients " nondominant arms and the patients were instructed to keep their arms still during BP measurements. All patients were asked to attend their usual activities and refrain from unusual activities such as consuming a lot of coffee, tea or alcohol and excessive physical exercise ${ }^{7}$. The measurements (daytime SBP-DBP, nighttime SBP-DBP, and 24-h SBP-DBP) were analyzed for each patient. Records with more than a $20 \%$ artifact in ABPM were not analyzed. The daytime was defined from 07:00 $A M$ to 22:00 PM, and the nighttime was from 22:00 PM to 07:00 AM. HT was defined as 24-h $\mathrm{SBP} / \mathrm{DBP}>130 / 80 \mathrm{mmHg}$, and/or daytime SBP/ DBP $>135 / 85 \mathrm{mmHg}$, and nighttime SBP/DBP $>120 / 70 \mathrm{mmHg}^{8}$. The percentage of nocturnal BP decline was calculated as (daytime BP - nighttime BP) $x 100 /$ daytime BP. Patients with $>10 \%$ decrease in either systolic or diastolic BP were considered to have dipper $\mathrm{HT}^{9}$.

\section{Neuropsychological testing:}

The HADS questionnaire was applied to evaluate the depression and anxiety levels of the patients during outpatient clinic visits. HADS consists of 14 questions with seven questions for depression (HADS-D) and seven questions for anxiety (HADS-A). Each question is scored between 0-3 points. The HADS-D score indicates the severity of depression, while the HADS-A score indicates the severity of anxiety, and higher scores indicate increased disease severity and vice versa. The national version of the HADS questionnaire has been proven and categorized with a cut-off score of 10 points for the depression, and 7 points for the anxiety subscale ${ }^{10}$.

We also compared these 142 patients with a control group of 83 primary hypertensive patients who underwent 24-h ABPM twice in the year before the pandemic. These control group patients were selected from our database of 24-h ABPM records using similar inclusion and exclusion criteria as in the study group. Similarly, these patients continued to use the same antihypertensive drugs during the follow-up period.

\section{Statistical Analysis}

All statistical analyzes were performed using the "rms," "Desctool", and "ggplot2" packages with the R-Software version 4.0 (R statistical software, The Institute for Statistics and Mathematics). The Shapiro-Wilk test and/or histograms were used to evaluate the normality of the variables. Normally distributed continuous variables were presented as mean \pm standard deviation. Non-normally distributed continuous variables were presented as the median and interquartile range (IQR $25^{\text {th }}$ $\left.75^{\text {th }}\right)$. Categorical variables were presented as numbers and percentages. The paired t-test or the Wilcoxon test was used to compare two groups for before and after BP measurements, depending on their distribution patterns. In addition, we divided the patients into a further two groups according to the HADS-A subscale score as low-grade $(<7)$ and high-grade $(\geq 7)$ anxiety. Continuous variables were compared with the Mann-Whitney $\mathrm{U}$ or independent samples t-test and categorical variables were compared by the chi-square test and Fisher exact test dependent on cell amount. The effect size (Cohen's d) and power value (1- $\beta$ ) of the study were calculated using $G^{*}$ Power software (version 3.1.9.2). The effect size and power value were 0.86 and 0.99 , respectively.

Primary outcome was the effect of pandemicrelated anxiety disorder on BP control

Candidate Predictors: Candidate predictors included in the model were chosen according to the literature, expert opinion and our focused variables. Accordingly, we included 10 candidate 
predictors; age, gender, waist circumference, BMI, HADS-A and HADS-D score, CAD, smoking, non-dipper $\mathrm{HT}$, and baseline 24-h SBP in our regression model.

The relative importance of each predictor in the regression model was estimated with the partial$X^{2}$ value, which estimates the independent contribution of the predictor to the variance of the outcome. In all statistical analyses, a two-tailed p-value of $<0.05$ was considered statistically significant.

\section{RESULTS}

This study consisted of 142 patients with primary HT. The demographic and clinical characteristics of the patients are shown in Table 1 . The mean age of the patients was 53.7 years, and $57 \%$ of them were male. Most of the patients $(85.2 \%)$ were using angiotensin-converting enzyme inhibitors (ACEIs) or angiotensin II receptor blockers (ARBs), calcium channel blockers (64\%), diuretics (65.5\%), beta-blockers (26.1\%), and alfa-blockers (11.3\%). All patients included in the study continued to use

Table 1. Baseline clinical characteristics of patients with well-controlled primary hypertension.

\begin{tabular}{|c|c|c|c|c|}
\hline & $\begin{array}{l}\text { All } \\
n=142\end{array}$ & $\begin{array}{l}\text { HADS-A }(<7) \\
\text { low HT group } \\
n=80\end{array}$ & $\begin{array}{l}\text { HADS-A }(\geq 7) \\
\text { high HT group } \\
n=62\end{array}$ & P value \\
\hline Age (years) & $53.7 \pm 11$ & $53.6 \pm 11.1$ & $53.9 \pm 11$ & 0.91 \\
\hline Gender (male) (n,\%) & $57(40.1)$ & $32(40)$ & $25(40.3)$ & 0.97 \\
\hline Pre-weight (kg) & $78.8 \pm 12.8$ & $78.5 \pm 12.9$ & $79.1 \pm 12.7$ & 0.76 \\
\hline Pre-BMI $\left(\mathrm{kg} / \mathrm{m}^{2}\right)$ & $28 \pm 4.11$ & $27.8 \pm 4.1$ & $28.3 \pm 4.14$ & 0.49 \\
\hline Pre-waist (cm) & $86.2 \pm 10.4$ & $84.8 \pm 10.8$ & $88 \pm 9.1$ & 0.06 \\
\hline Post-weight (kg) & $79.6 \pm 12.6$ & $78.5 \pm 12.3$ & $81 \pm 13$ & 0.24 \\
\hline Post-BMI $\left(\mathrm{kg} / \mathrm{m}^{2}\right)$ & $29.3 \pm 4.06$ & $28.9 \pm 3.82$ & $29.9 \pm 4.30$ & 0.18 \\
\hline Post-waist $(\mathrm{cm})$ & $86.4 \pm 10.4$ & $84.8 \pm 10.7$ & $86.6 \pm 9.67$ & $0.03^{*}$ \\
\hline HADS-A & $7.04 \pm 3.10$ & & & \\
\hline HADS-D & $6.35 \pm 2.58$ & $4.49 \pm 1.64$ & $8.74 \pm 1.24$ & $<0.001^{*}$ \\
\hline HL (n,\%) & $18(12.7)$ & $10(12.5)$ & 8 (12.9) & 0.94 \\
\hline CAD $(n, \%)$ & $6(4.2)$ & $3(3.8)$ & $3(4.8)$ & 0.75 \\
\hline Smoking (n,\%) & $43(30.3)$ & $23(28.7)$ & $20(32.3)$ & 0.65 \\
\hline Beta-blocker (n,\%) & $37(26.1)$ & $19(23.8)$ & $18(29)$ & 0.47 \\
\hline Dihidropiridin CaCB (n,\%) & $80(56.3)$ & $42(52.5)$ & $38(61.3)$ & 0.29 \\
\hline Non-dihidropiridin CaCB $(\mathrm{n}, \%)$ & $11(7.7)$ & $7(8.8)$ & $4(6.5)$ & 0.61 \\
\hline ACEI-ARB $(n, \%)$ & $121(85.2)$ & $70(87.5)$ & $51(82.5)$ & 0.38 \\
\hline Alfa-blocker (n,\%) & $16(11.3)$ & $10(12.5)$ & $6(9.7)$ & 0.59 \\
\hline Diuretic $(n, \%)$ & $93(65.5)$ & $49(61.3)$ & $44(71)$ & 0.22 \\
\hline Non dipper (n,\%) & $59(41.5)$ & $32(40)$ & $27(43.5)$ & 0.67 \\
\hline Pre-Day SBP (mmHg) & $128 \pm 5.19$ & $129 \pm 4.47$ & $128 \pm 5.97$ & 0.17 \\
\hline Pre-Day DBP (mmHg) & $80.1 \pm 3.83$ & $80.2 \pm 3.67$ & $79.9 \pm 4.06$ & 0.62 \\
\hline Pre-Night SBP (mmHg) & $116 \pm 5.16$ & $116 \pm 4.59$ & $115 \pm 5.79$ & 0.21 \\
\hline Pre-Night DBP (mmHg) & $67.5 \pm 3.69$ & $67.4 \pm 2.35$ & $67.5 \pm 4.92$ & 0.78 \\
\hline Pre-24-h SBP (mmHg) & $124 \pm 5.55$ & $125 \pm 4.44$ & $124 \pm 6.69$ & 0.16 \\
\hline Pre-24-h DBP (mmHg) & $75.9 \pm 3.19$ & $76.1 \pm 2.94$ & $75.8 \pm 3.5$ & 0.56 \\
\hline Post-Day SBP (mmHg) & $135.2 \pm 6.87$ & $132 \pm 5.51$ & $139 \pm 6.22$ & $<0.001^{*}$ \\
\hline Post-Day DBP (mmHg) & $84.2 \pm 4.95$ & $81.9 \pm 4.31$ & $87.1 \pm 4.16$ & $<0.001 *$ \\
\hline Post-Night SBP (mmHg) & $120.4 \pm 5.80$ & $118 \pm 5.37$ & $123 \pm 5.35$ & $<0.001^{*}$ \\
\hline Post-Night DBP (mmHg) & $70.7 \pm 4.59$ & $69 \pm 3.39$ & $72.9 \pm 4.98$ & $<0.001^{*}$ \\
\hline Post-24-h SBP (mmHg) & $130.2 \pm 6.37$ & $128 \pm 5.57$ & $134 \pm 5.75$ & $<0.001 *$ \\
\hline Post-24-h DBP (mmHg) & $79.9 \pm 4.39$ & $77.7 \pm 3.70$ & $82.7 \pm 3.50$ & $<0.001^{*}$ \\
\hline
\end{tabular}

$p<0.05$

Abbreviations: BMI: body mass index; HADS-A: hospital anxiety and depression scale-anxiety; HADS-D: hospital anxiety and depression scale-depression; HL: hyperlipidemia; CAD: coronary artery disease; CaCB: calcium channel blocker; ACEI: angiotensinconverting enzyme inhibitor; ARB: angiotensin receptor blocker; SBP: systolic blood pressure; DBP: diastolic blood pressure. Data were expressed as mean values $\pm S D$ or number (\%) of patients.

The low HADS-A group consisted of hypertensive patients with an anxiety score $<7$, and the high HADS-A group consisted of hypertensive patients with an anxiety score of $\geq 7$. 
the same medications throughout their follow-up (before and during the pandemic).

The mean HADS anxiety and depression subscale scores were $7.04 \pm 3.10$ and $6.35 \pm 2.58$, respectively. In terms of the HADS cut-off points, $43.6 \%$ of the study population scored above the anxiety cut-off value (HADS-A $\geq 7$ ), and $18.3 \%$ above the depression cut-off value (HADS-D $\geq 10$ ). Patients were classified into two groups according to their anxiety levels as low $(<7)$ and high $(\geq 7)$ based on HADS-A scores. Depression scores were also significantly higher in the group with high anxiety levels $(p<0.001)$. There was no significant difference between the groups in terms of demographic characteristics and antihypertensive drug use. Weights and BMIs of the study patients also did not change significantly during follow-up (Table 1).

Table 2 shows 24-h- ABPM values of the study patients before and during the pandemic. Daytime, nighttime and 24-h- SBP as well as daytime, nighttime and 24-h- DBP values were found to be significantly elevated during the pandemic compared to the pre-pandemic period $(p<0.001)$. Since the overall differences in BP values before and during the pandemic reflect both the pandemic effect and other trends, such as periodic effects, that may affect BP during this period, we compared these patients with a group of control patients who did not experience a pandemic. In this control group, there was no significant change in the mean BP values after 12 months of follow-up (Table 2).

In addition, we compared the average BP values before and during the pandemic according to the anxiety levels of the study patients. The mean BP values were similar between two groups before the pandemic. However, both systolic and diastolic mean BP values were much higher in the group with higher HADS-A scores than in the patients with lower HADS-A scores $(p<0.001)$ (Table 1, Figure 1).

We conducted a multivariate linear regression model to identify the potential risk factors associated with the increase in 24-h- SBP levels during the pandemic. Higher HADS-A (from 5 to 10 points) levels and HADS-D (from 4 to 9 points) scores were associated with increased 24-h- SBP values during the pandemic, regardless of prepandemic BP values. Higher baseline 24-h- SBP (from 123 to $128 \mathrm{mmHg}$ ) levels and advanced age (from 46 to 62 years) in the pre-pandemic period were also associated with an increase in 24-h- SBP during the pandemic (Table 3). A high baseline BP value was found as the most contributing predictor for the 24-h SBP elevation during the pandemic. The second most important variable was a higher HADS-A score (Figure 2).

Table 2. Blood pressure levels before and during the pandemic in the study patients and control group.

\begin{tabular}{|c|c|c|c|c|c|c|}
\hline & \multicolumn{3}{|c|}{$\begin{array}{l}\text { Study group } \\
\mathrm{n}=142\end{array}$} & \multicolumn{3}{|c|}{$\begin{array}{c}\text { Control group } \\
n=83\end{array}$} \\
\hline & Before pandemic & During pandemic & p value & Before control & After control & p value \\
\hline Daytime SBP (mmHg) & $128.5 \pm 5.19$ & $135.2 \pm 6.87$ & $<0.001^{*}$ & $129 \pm 4.88$ & $130.1 \pm 5.53$ & 0.08 \\
\hline Daytime DBP (mmHg) & $80.1 \pm 3.83$ & $84.2 \pm 4.95$ & $<0.001^{*}$ & $78.9 \pm 4.33$ & $79.4 \pm 4.97$ & 0.43 \\
\hline Nighttime SBP (mmHg) & $116 \pm 5.16$ & $120.4 \pm 5.80$ & $<0.001^{*}$ & $114 \pm 4.79$ & $113.4 \pm 4.23$ & 0.23 \\
\hline Nighttime DBP (mmHg) & $67.5 \pm 3.69$ & $70.7 \pm 4.59$ & $<0.001^{*}$ & $65.4 \pm 2.15$ & $64.9 \pm 2.77$ & 0.11 \\
\hline 24-h SBP (mmHg) & $124 \pm 5.55$ & $130.2 \pm 6.37$ & $<0.001^{*}$ & $122.6 \pm 5.15$ & $123.5 \pm 5.48$ & 0.10 \\
\hline 24-h DBP (mmHg) & $75.9 \pm 3.19$ & $79.9 \pm 4.39$ & $<0.001^{*}$ & $74.5 \pm 3.53$ & $73.9 \pm 3.82$ & 0.16 \\
\hline
\end{tabular}

${ }^{*} p<0.05$

Abbreviations: SBP: systolic blood pressure; DBP: diastolic blood pressure. 
Table 3. Risk factors for 24-h SBP elevation during the pandemic according to univariate and multivariate linear regression models.

\begin{tabular}{|c|c|c|c|c|}
\hline Variables & $\begin{array}{l}\text { Univariate, } \\
\beta \text {-coefficient, CI }\end{array}$ & p value & $\begin{array}{l}\text { Multivariate, } \\
\beta \text {-coefficient, CI }\end{array}$ & P value \\
\hline Age (from 46 to 62 years) & $0.28(-1.25,1.82)$ & 0.71 & $0.88(0.12,1.65)$ & $0.02^{*}$ \\
\hline Gender (male) & $-1.88(-4.01,0.25)$ & 0.08 & $-0.58(-1.90,0.74)$ & 0.38 \\
\hline Baseline Waist circumference $(82-92 \mathrm{~cm})$ & $0.21(-0.80,1.24)$ & 0.67 & $0.25(-0.43,0.93)$ & 0.46 \\
\hline Baseline BMI (25 to $30.75 \mathrm{~kg} / \mathrm{m}^{2}$ ) & $0.35(-1.13,1.83)$ & 0.64 & $0.35(-0.52,1.23)$ & 0.42 \\
\hline HADS-A (5-10 points) & $5.05(3.74,6.36)$ & $<0.001$ & $3.76(1.79,5.73)$ & $<0.001$ * \\
\hline HADS-D (4-9 points) & $6.73(5.10,8.36)$ & $<0.001$ & $1.24(0.40,5.33)$ & $0.02^{*}$ \\
\hline CAD & $1.63(-3.61,6.88)$ & 0.53 & $1.25(-1.32,3.83)$ & 0.33 \\
\hline Smoking & $-1.18(-3.47,1.10)$ & 0.31 & $-0.42(-1.54,0.69)$ & 0.45 \\
\hline Non-Dipper & $0.28(-1.86,2.42)$ & 0.79 & $0.60(-0.41,1.63)$ & 0.24 \\
\hline Baseline 24-h SBP (from 123 to $128 \mathrm{mmHg}$ ) & $0.38(2.76,4.27)$ & $<0.001$ & $3.93(3.47,4.40)$ & $<0.001^{*}$ \\
\hline
\end{tabular}

${ }^{*} p<0.05$

Abbreviations: BMI: body mass index; HADS-A: hospital anxiety and depression scale-anxiety; HADS-D: hospital anxiety and depression scale-depression; CAD: coronary artery disease; SBP: systolic blood pressure.

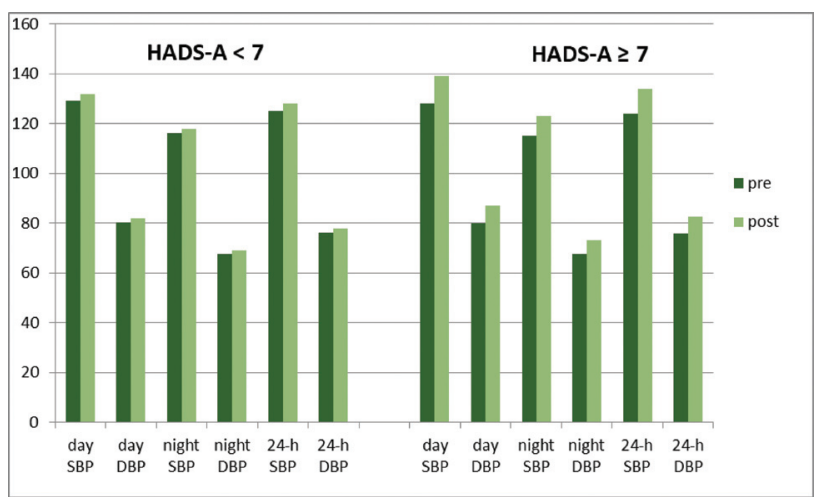

Figure 1. The change in blood pressure during the pandemic according to the HADS-A scores.

Change in $B P$ between the period before and during the pandemic according to the HADS-A score. Patients with higher HADS-A scores (HADS-A $\geq 7$ ) are significantly associated with much greater increase in $B P$ than patients with lower HADS-A scores;

HADS-A, hospital anxiety and depression scale-anxiety

\section{DISCUSSION}

The present study demonstrates that BP in primary hypertensive patients increased significantly during the COVID-19 outbreak compared to the pre-pandemic period. This increase in BP was significantly associated with increases in HADS-A and HADS-D scores, especially in elderly patients with higher baseline BPs.

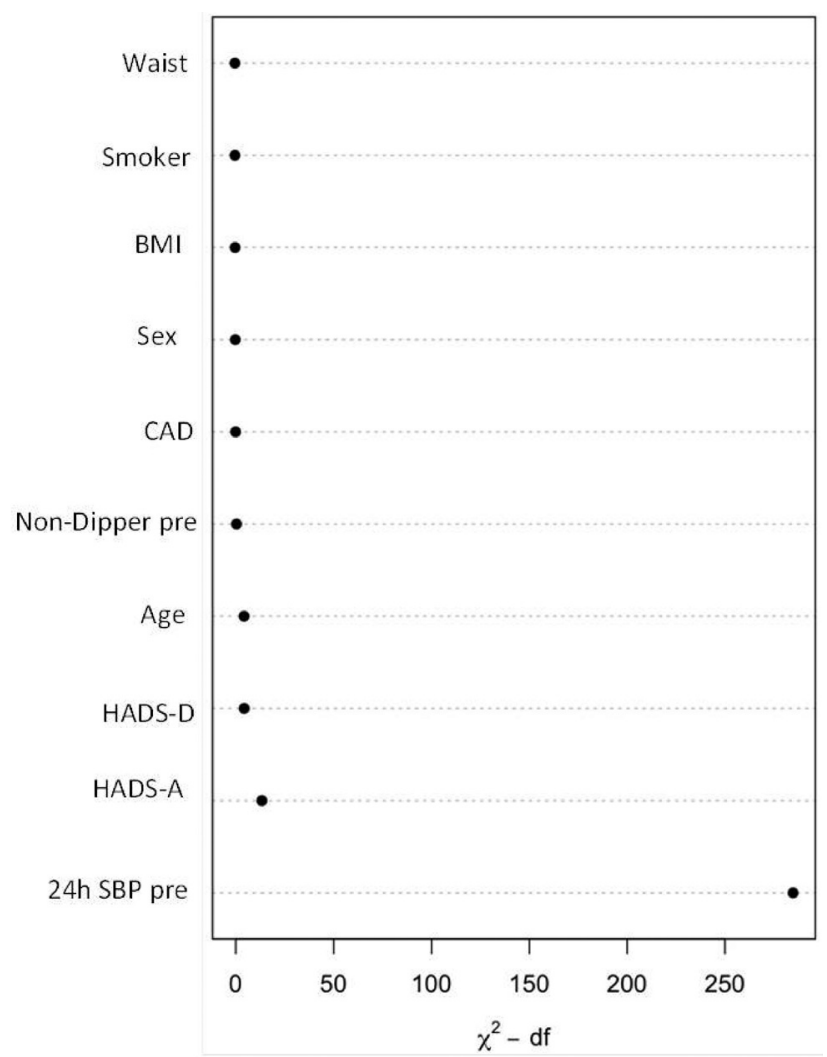

Figure 2. Relative importance of each variables in linear regression model.

Relative importance of each variable in regression model. The most important variable is higher 24-h SBP at baseline,followed by higher HADS-A, HADS-D scores, and advanced age, respectively.

HADS-A, hospital anxiety and depression scale-anxiety; HADS-D, hospital anxiety and depression scale-depression. 
Social isolation due to the COVID-19 outbreak led to depression and poorer mental health in people ${ }^{11}$. In a study conducted in Northern Spain, psychological stress was low in humans in the first few days of the COVID-19 outbreak; however, in association with the requirement for quarantine, people's stress, anxiety, and depression levels increased significantly ${ }^{12}$. Similarly, we found relatively high anxiety and depression rates (43.6\% and $18.3 \%$, respectively) during the COVID-19 outbreak.

Anxiety disorders cause an increase in BP by activating the sympathetic nervous system and the hypothalamus-pituitary-adrenal (HPA) axis ${ }^{13}$. Previous studies have also revealed a strong association between depression and these two systems ${ }^{14}$. In the light of this knowledge, we investigated the effect of pandemic-related stress on BP and found that daytime, nighttime, and 24hour- SBP and DBP levels increased significantly compared to the pre-pandemic BP levels. In line with this, our control group who did not experience a pandemic showed no significant BP increment during one year follow-up. We also showed that the patients with higher HADS-A scores (HADS-A $\geq 7$ ) were significantly associated with much greater increase in BP than the patients with lower HADS-A scores.

Similarly, increased psychological stress in earthquake survivors was identified as an independent risk factor for BP increase ${ }^{15}$. Paolo Giorgini et al. ${ }^{16}$ found a marked increase in daytime, nighttime and 24-h- SBP and DBP levels in patients with primary hypertension after the 2009 L'Aquila earthquake. The YaAn earthquake also caused a $3.3 \mathrm{~mm} \mathrm{Hg}$ increase in mean SBP levels among hospitalized patients compared to the non-disaster group ${ }^{17}$. Consistent with these results, sympatholytics were reported to have beneficial effects on poor BP control caused by psychological stress during a natural disaster ${ }^{18}$. Although the exact mechanism is unknown, periods of anxiety disorders caused by natural disasters such as earthquakes and pandemics trigger the adrenergic system. This sympathetic arousal causes increase in heart rate and decrease in blood vessel diameter, and consequently results in increasing BP4.

Stress-related increase in BP is more common, especially in elderly patients since the hypothalamus-pituitary-adrenal (HPA) axis responsivity to stress increases with aging ${ }^{19,20}$. In the study by Kario et al. ${ }^{21}$ aging and chronic renal failure were also associated with sympathetic nerve overactivity. Similarly, increased psychological stress due to the pandemic was significantly associated with a much greater increase in BP, especially in elderly patients in our study.

A high baseline BP is an important predictor for the increase in BP after an earthquake ${ }^{22}$. The YaAn earthquake also showed that the SBP level at hospital admission was positively associated with the increased SBP following the earthquake ${ }^{17}$. In line with these results, it is worth noting that in the current study, compared to the lower baseline BP levels, higher baseline 24-h- SBP (increased from 123 to $128 \mathrm{mmHg}$ ) levels were significantly associated with poor BP control during the pandemic.

\section{Study limitations}

This study has several limitations. Firstly, we evaluated a relatively small number of patients from a single center. The small number of patients included in the study may be due to the restriction of hospital admissions, other than emergencies, and the reduction in outpatient visits due to the risk of COVID-19 transmission. Secondly, changes in dietary habits and daily exercise that may contribute to an increase in BP were not analyzed in the present study. However, this limitation does not affect the aim of our study since there was no significant increase in weight and BMI of the study patients during the pandemic which was also supported by the fact that BP values did not change significantly during a 12-month 
follow-up in a group of control patients who did not experience a pandemic. Finally, we did not investigate the long-term effects of the COVID-19 outbreak on BP control, and when BP will return to normal levels. In spite of these limitations, the present study clearly demonstrated that pandemicrelated anxiety disorders caused impaired BP control in primary hypertensive patients.

\section{CONCLUSION}

Psychological stress due to the COVID-19 outbreak led to worsening of BP in controlled hypertensive patients whose antihypertensive treatments did not change. Therefore, it should be noted that BP control should be tighter, and appropriate modulation of antihypertensive drugs should be taken into consideration during the pandemic.

\section{REFERENCES}

1. Qiu J, Shen B, Zhao M, Wang Z, Xie B, Xu Y. A nationwide survey of psychological distress among Chinese people in the COVID-19 epidemic: implications and policy recommendations. Gen Psychiatr. 2020;33:e100213. [CrossRef]

2. Liu S, Yang L, Zhang C, et al. Online mental health services in China during the COVID-19 outbreak. Lancet Psychiatry. 2020;7:e17-8. [CrossRef]

3. Gao J, Zheng P, Jia Y, et al. Mental health problems and social media exposure during COVID-19 outbreak. PLoS One. 2020;15:e0231924. [CrossRef]

4. Kario K, McEwen BS, Pickering TG. Disasters and the heart: a review of the effects of earthquake-induced stress on cardiovascular disease. Hypertens Res. 2003;26:355-67. [CrossRef]

5. Irigoyen MC, De Angelis K, Dos Santos F, Dartora DR, Rodrigues B, Consolim-Colombo FM. Hypertension, blood pressure variability, and target organ lesion. Curr Hypertens Rep. 2016;18:31. [CrossRef]

6. Sensoy B, Gunes A, Ari S. Anxiety and depression levels in Covid-19 disease and their relation to hypertension. Clin Exp Hypertens. 2021;43:237-41. [CrossRef]

7. White WB, Lund-Johansen P, Omvik P. Assessment of four ambulatory blood pressure monitors and measurements by clinicians versus intraarterial blood pressure at rest and during exercise. Am J Cardiol. 1990;65:60-6. [CrossRef]

8. Williams B, Mancia G, Spiering W, et al. 2018 Practice Guidelines for the management of arterial hypertension of the European Society of Hypertension and the European Society of Cardiology: ESH/ESC Task Force for the Management of Arterial Hypertension. J Hypertens. 2018;36:2284-309. [CrossRef]

9. Chobanian AV, Bakris GL, Black HR, et al. The Seventh Report of the Joint National Committee on Prevention, Detection, Evaluation, and Treatment of High Blood Pressure: the JNC 7 report. JAMA. 2003;289:2560-72. [CrossRef]

10. Aydemir, O. Reliability and validity of the Turkish version of Hospital Anxiety and Depression Scale. Turkish Journal of Psychiatry. 1997;8:280-7.

11. Brooks SK, Webster RK, Smith LE, et al. The psychological impact of quarantine and how to reduce it: rapid review of the evidence. Lancet. 2020;395:912-20. [CrossRef]

12. Ozamiz-Etxebarria N, Dosil-Santamaria M, PicazaGorrochategui M, Idoiaga-Mondragon N. Stress, anxiety, and depression levels in the initial stage of the COVID-19 outbreak in a population sample in the northern Spain. Cad Saude Publica. 2020;36:e00054020. [CrossRef]

13. Kalsner S. Mechanism of hydrocortisone potentiation of responses to epinephrine and norepinephrine in rabbit aorta. Circ Res. 1969;24:383-95. [CrossRef]

14. Russek LG, King SH, Russek SJ, Russek HI. The Harvard Mastery of Stress Study 35-year follow-up: prognostic significance of patterns of psychophysiological arousal and adaptation. Psychosom Med. 1990;52:271-85. [CrossRef]

15. Kario K, Matsuo T, Kobayashi H, Yamamoto K, Shimada $\mathrm{K}$. Earthquake-induced potentiation of acute risk factors in hypertensive elderly patients: possible triggering of cardiovascular events after a major earthquake. J Am Coll Cardiol. 1997;29:926-33. [CrossRef]

16. Giorgini P, Striuli R, Petrarca M, et al. Long-term blood pressure changes induced by the 2009 L'Aquila earthquake: assessment by $24 \mathrm{~h}$ ambulatory monitoring. Hypertens Res. 2013;36:795-8. [CrossRef]

17. Li C, Luo X, Zhang W, Zhou L, Wang H, Zeng C. YaAn earthquake increases blood pressure among hospitalized patients. Clin Exp Hypertens. 2016;38:495-9. [CrossRef]

18. Kario K, Matsuo T, Shimada K, Pickering TG. Factors associated with the occurrence and magnitude of earthquake-induced increases in blood pressure. Am J Med. 2001;111:379-84. [CrossRef]

19. Raskind MA, Peskind ER, Wilkinson CW. Hypothalamicpituitary-adrenal axis regulation and human aging. Ann N Y Acad Sci. 1994;746:327-35. [CrossRef]

20. Kario K. Disaster hypertension -its characteristics, mechanism, and management-. Circ J. 2012;76:553-62. [CrossRef]

21. Kario K, Nishizawa M, Hoshide S, et al. Development of a disaster cardiovascular prevention network. Lancet. 2011;378:1125-7. [CrossRef]

22. Tanaka K, Nakayama M, Kanno M, et al. Home blood pressure control after the great East Japan earthquake in patients on chronic hemodialysis. Ther Apher Dial. 2014;18:149-54. [CrossRef] 